\title{
Fructose and/or sorbitol intolerance in a subgroup of lactose intolerant patients
}

\author{
SR MISHKIN BA, L SABLAUSKAS BSc, S MISHKIN MD FRCPC
}

SR MISHKIN, L SABLAUSKAS, S MISHKIN. Fructose and/or sorbitol intolerance in a subgroup of lactose intolerant patients. Can J Gastroenterol $1994 ; 8(6): 389-393$. The diagnosis and treatment of lactose intolerance often does not resolve all the symptoms of postcibal bloating and flatulence. Included in this study were 104 lactose intolerant patients ( 71 female, 33 male) who complained of residual postcibal discomfort in spite of adherence to and benefit from appropriate measures for their documented lactose intolerance (at least 20 ppm $\mathrm{H}_{2}$ after $25 \mathrm{~g}$ lactose as well as appropriate symptomatic discomfort). Clinical characteristics common to this group included: symptomatic diarrhea $(12.5 \%)$, history of foreign travel $(5.8 \%)$, endoscopic and pathological evidence of gastritis and helicobacter infection (19.2 and $8.7 \%$, respectively), nonspecific abnormalities of small bowel follow-through (15.4\%), Crohn's disease $(8.7 \%)$ and colonic diverticulosis (14.4\%). Intolerance to fructose (at least $10 \mathrm{ppm} \mathrm{\textrm {H } _ { 2 }}$ after $25 \mathrm{~g}$ fructose plus appropriate symptoms) or sorbitol (at least $10 \mathrm{ppm} \mathrm{H}_{2}$ after $5 \mathrm{~g}$ sorbitol plus appropriate symptoms) was documented in 17.3 and $18.3 \%$, respectively. Intolerance to both fructose and sorbitol (administered as separate challenges), more than twice as common as intolerance to either one alone, occurred in $41.4 \%$ and was independent of sex. In conclusion, additional carbohydrate intolerances contribute to postcibal discomfort in more than $75 \%$ of lactose intolerant patients who remain symptomatic in spite of adherence to appropriate measures for this condition. While $62 \%$ of all patients had benefited significantly (greater than 50\%) from appropriate dietary measures and enzyme replacement for lactose intolerance, only $40 \%$ of those who were also fructose intolerant and $47 \%$ who were sorbitol intolerant benefited (greater than $50 \%$ ) from appropriate dietary measures (no enzyme replacement yet available) for intolerance to these sugars.

Key Words: Carbohydrate intolerance, $\mathrm{H}_{2}$ breath testing, Lactose intolerance

\section{Intolérance au fructose et/ou au sorbitol chez un sous-groupe de patients souffrant d'intolérance au lactose}

RÉSUMÉ : Le diagnostic et le traitement de l'intolérance au lactose ne règle pas tous les symptômes de ballonnement et de flatulences postprandiaux. Furent inclus dans cette étude 104 patients intolérants au lactose (71 femmes et

\section{voir page suivante}

Division of Gastroenterology, Royal Victoria Hospital, Department of Medicine, McGill University, Montreal, Quebec

Correspondence and reprints: Dr Seymour Mishkin, 5506 Elgin Avenue, Montreal, Quebec H4V 2G8. Telephone (514) 932-2686

Received for publication January 6, 1994. Accepted May 19, 1994
T HE VALUE OF TESTING FOR SPECific carbohydrate intolerances is the subject of much debate. It is generally accepted that while patients with irritable bowel syndrome (IBS) will experience more discomfort after ingesting a substance to which they are intolerant (1-3), the incidence of fructose-sorbitol intolerance is not increased compared with normal controls (1) and hence cannot be implicated as an etiological factor in this very common condition. In contrast to reactions observed in patients with food allergies and celiac disease, the specific offenders being considered in IBS patients do not produce any known deleterious effects on the gastrointestinal tract. Estimates of the incidence of fructose and sorbitol malabsorption in the general population range between 37.5 and $50 \%$ and between 10 and $60 \%$, respectively, depending on the dose challenge used (4-6). In view of the relatively high prevalence of these intolerances in normal populations, it appears that we are dealing with the saturation of low capacity absorptive systems rather than pathophysiological conditions. Whether we are dealing with physiological or pathophysiological entities, malabsorbed fructose and sorbitol can lead to real symptoms. Bacterial fermentation of malabsorbed sugars leads to the production of distressing, albeit beneficial, gases and short chain fatty acids such as propionate, butyrate and acetic acid $(7,8)$.

The aim of this study was to deter- 
33 hommes) qui se plaignaient de malaises postprandiaux résiduels malgré les mesures thérapeutiques appropriées pour leur intolérance avérée au lactose (minimum de 20 ppm de $\mathrm{H}_{2}$ après $25 \mathrm{~g}$ de lactose et symptômes concordants). Les caractéristiques cliniques communes à ce groupe comprenaient : diarrhée symptomatique $(12,5 \%)$, antécédents de voyages à l'étranger $(5,8 \%)$, signes endoscopiques et pathologiques de gastrite et d'infection à Helicobacter $(19,2 \%$ et $8,7 \%$ respectivement), anomalies non spécifiques de l'intestin grêle $(15,4 \%)$, maladie de Crown $(8,7 \%)$ et diverticulose du côlon $(14,4 \%)$. L'intolérance au fructose (au moins $10 \mathrm{ppm}$ de $\mathrm{H}_{2}$ après $25 \mathrm{~g}$ de fructose et symptômes concordants) ou au sorbitol (au moins 10 ppm de $\mathrm{H}_{2}$ après $5 \mathrm{~g}$ de sorbitol et symptômes concordants) a été documentée chez 17,3 et 18,3\% des sujets respectivement. L'intolérance à la fois au fructose et au sorbitol (administrés lors de tests de provocation distincts), plus de deux fois plus fréquente que l'intolérance à l'un ou à l'autre seule, a été observée chez $41,4 \%$ des sujets, indépendamment du sexe. En conclusion, les intolérances additionnelles aux glucides contribuent aux malaises postprandiaux chez plus de $75 \%$ des patients intolérants au lactose qui demeurent symptomatiques malgré l'application de mesures qui s'imposent vu leur état. Alors que $62 \%$ de tous les patients avaient tiré un avantage marqué (plus de $50 \%$ ) d'une diétothérapie appropriée et d'un traitement enzymatique substitutif pour l'intolérance au lactose, seulement $40 \%$ de ceux qui étaient aussi intolérants au fructose et $47 \%$ de ceux qui étaient intolérants au sorbitol ont bénéficié (plus de $50 \%$ ) d'une diétothérapie appropriée (aucun traitement enzymatique substitutif encore disponible) pour l'intolérance vis-à-vis de ces sucres.

mine the incidence and significance of fructose and/or sorbitol intolerance in a group of lactose intolerant patients, all of whom had continued to experience clinically significant postcibal discomfort even after dietary guidance and the use of the appropriate enzyme replacement (beta-galactosidase) had provided variable degrees of relief from their lactose-related symptoms. Were there any clinical characteristics, including pathological entities, that could predict which patients would manifest additional carbohydrate intolerances, and would their postcibal discomfort benefit from a modification of the intake of the offending sugars?

\section{PATIENTS}

The lactose intolerant population studied continued to complain of postcibal discomfort even after appropriate dietary guidance and beta-galactosidase enzyme replacement, and was derived from the private practice of a single gastroenterologist. One hundred and four consecutive patients (at least 18 years old; $68.3 \%$ female) with documented lactose intolerance (at least a $20 \mathrm{ppm}$ rise in breath $\mathrm{H}_{2}$ as well as symptomatic discomfort after ingesting 25 g lactose as a $10 \%$ solution) (Table 1) were selected. The majority of the patients could be classified as having IBS except for $8.7 \%$ with Crohn's disease of the distal small bowel (terminal ileum). The predominance of females in the IBS population seeking medical evaluation has been discussed by Thompson (9). The diagnosis of IBS was based on accepted clinical criteria only after organic gastrointestinal disease had been excluded. Each patient had undergone at least a complete history and physical examination, full blood cell count, biochemical profile including liver-related enzymes, stool analysis for parasites, ova, bacterial pathogens and blood, as well as a small bowel follow-through and flexible sigmoidoscopy. Proceeding from the premise that the incidence of intolerance to fructose and sorbitol was not more prevalent in IBS patients (1) the authors did not attempt to assemble a control group of nonlactose intolerant IBS patients. As explained in the discussion this would have been a most difficult task and it is doubtful that a valid 'control group' could have been chosen.

\section{METHODS}

Following an overnight fast and avoidance of gas-producing foods as well as fibre and cigarettes for the prior
TABLE 1

Criteria for carbohydrate intolerance: positive $\mathrm{H}_{2}$ breath test plus symptoms

\begin{tabular}{lcc}
\hline $\begin{array}{l}\text { Sugar } \\
\text { tested }\end{array}$ & Dose & $\begin{array}{c}\text { Criteria for } \\
\text { malabsorption }\end{array}$ \\
\hline Lactose & $25 \mathrm{~g}$ & $\geq 20$ ppm rise \\
Fructose & $25 \mathrm{~g}$ & $\geq 10$ ppm rise \\
Sorbitol & $5 \mathrm{~g}$ & $\geq 10$ ppm rise \\
\hline
\end{tabular}

ppm Parts per million

$24 \mathrm{~h}$, patients were given either $25 \mathrm{~g}$ fructose or $5 \mathrm{~g}$ sorbitol as $10 \%$ solutions on separate occasions (at least one week apart). The carbohydrate challenge was cancelled if there was a history of systemic illness, gastroenteritis or use of antibiotics within two weeks of testing. Levels of end-expiratory breath $\mathrm{H}_{2}$ were determined at time 0 and every 15 mins thereafter for a total of $3 \mathrm{~h}$ with a hand-held Jayco $\mathrm{H}_{2}$ analyzer (Portsmouth, United Kingdom) which was standardized monthly against a Quintron clinical microlyzer (model CMZ) (Wisconsin). In addition to $\mathrm{H}_{2}$ concentration, symptoms of nausea, flatulence, cramping and diarrhea were recorded during the subsequent $3 \mathrm{~h}$. Intolerance to fructose and/or sorbitol was based on a rise of at least $10 \mathrm{ppm}$ in $\mathrm{H}_{2}$ concentration as well as the development of significant symptoms (Table 1). Testing of patients and interpretation of results were carried out. Questionnaires were filled out in the presence of one of the investigators during a follow-up visit at least six months after completion of these investigations and the initiation of appropriate dietary recommendations. Only patients with either fructose and/or sorbitol intolerance in addition to lactose intolerance were asked to complete the questionnaires. Sixty of 80 patients $(75 \%)$ who fell into these categories completed the questionnaire. The remaining 24 patients were not approached because the etiology of their postcibal discomfort had not been elucidated by the investigations.

Testing for equality of proportions was the statistical methodology employed and the P values of the significant tests are provided with the results. 


\section{RESULTS}

Based upon a review of all patient charts, clinical characteristics documented in at least $5 \%$ of the patients studied were analyzed. A history of diarrhea $(12.5 \%)$ was significantly more common in males $(21.2 \%)$ than in females $(8.5 \%)(\mathrm{P}<0.065)$, while a history of foreign travel $(5.8 \%)$ was elicited in $7 \%$ of females compared with 3\% of males (not significant). Gastritis and the presence of helicobacter, as determined by biopsy of the gastric antrum at gastroscopy, were present in $19.2 \%$ of males and $8.7 \%$ of females, respectively. Nonspecific radiological abnormalities of the small bowel (small bowel follow-through) (ie, 'disordered' small bowel pattern or mild nodularity) were noted in $15.4 \%$ of patients. Except for an additional $8.7 \%$ of patients who were diagnosed to have Crohn's disease of the distal small intestine, no cases of proven celiac disease or other pathological entity of the small intestine were documented. Diverticulosis mostly of the distal colon was present in $14.4 \%$ of the patient population. No significant sex-related differences were obtained in the above-mentioned categories. Analysis of the female subgroups according to specific carbohydrate intolerances indicated less foreign travel in patients with all three intolerances compared with those with either fructose or sorbitol intolerance in addition to lactose intolerance. No other significant differences were noted among the female subgroups analyzed. The number of male patients (33) was too small to permit a similar analysis.

In this group of lactose intolerant patients studied $(\mathrm{n}=104)$, additional intolerance to either fructose or sorbitol was documented in 15.2 and $24.2 \%$ of males and in 18.3 and $15.5 \%$ of $\mathrm{fe}$ males, respectively (Figure 1). The striking finding was that additional intolerance to both fructose and sorbitol was documented in $36.4 \%$ of males and $43.7 \%$ of females. The latter figure for females was approximately twice as great as that for intolerance to either fructose or sorbitol alone, and the hypothesis of equal proportions across the three subgroups was significant at $\mathrm{P}<0.005$. Although the same trend was

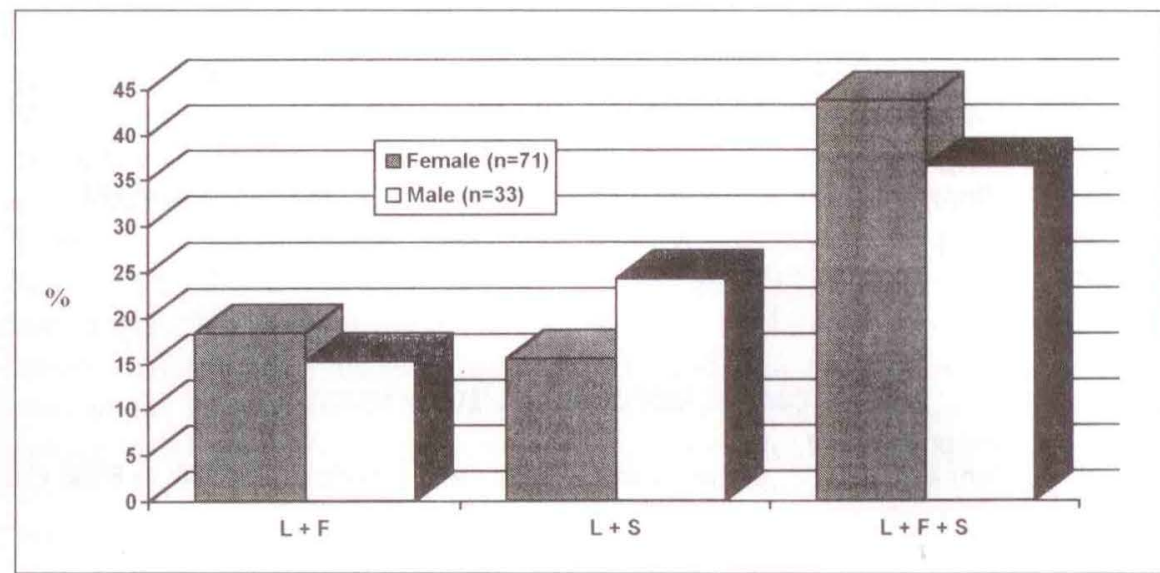

Figure 1) Percentage incidence of intolerance to fructose (F) and/or sorbitol (S) in 'symptomatic' lactose ( $\mathrm{L}$ ) intolerant patients. Oral challenges consisting of either $25 \mathrm{~g} \mathrm{~F}$ or $5 \mathrm{~g} \mathrm{~S}$ were administered separately. A positive test (indicating intolerance) was based on a rise of breath $\mathrm{H}_{2}$ of at least 10 parts per million with associated symptoms (bloating, cramping, pain, diarrhea). The incidence of combined $F$ and $S$ intolerance in females was significantly greater $(P<0.05)$ than to either sugar alone

apparent for males, the difference was not statistically significant. Irrespective of sex, therefore, more that $75 \%$ of the symptomatic lactose intolerant patients studied had at least one additional carbohydrate intolerance as documented by the testing.

Patient feedback was obtained with the help of a questionnaire completed approximately six to 12 months after the completion of investigation and dietetic counselling by 60 patients with at least two demonstrated sugar intolerances of which $78 \%$ were females ( $\mathrm{Ta}$ ble 2). Clearly, although adherence to appropriate dietary measures and the perception of symptomatic benefit were greatest with respect to symptoms of lactose intolerance, clinically significant postcibal symptoms were still experienced (a criterium for inclusion in this study). While $75 \%$ of patients classified lactose intolerance as a major problem, symptoms resulting from intolerance to fructose and sorbitol were similarly rated in only 60 and $55 \%$ of cases, respectively. With respect to symptoms of lactose intolerance, $62 \%$ of patients felt that they had experienced a symptomatic improvement of at least $50 \%$ with adherence to appropriate measures, while $13 \%$ had not experienced any significant relief. The corresponding figures for symptoms related to fructose and/or sorbitol intolerance indicated similar values for no relief ( 13 to $16 \%$ ) while significant relief (greater than 50\%) was noted in only 40 to $47 \%$ of these patients. Ninety-two per cent of patients claimed adherence to appropriate dietary measures for lactose intolerance, while approximately $85 \%$ of patients with additional intolerances to fructose or sorbitol did the same. Analysis of the data for the different subgroups of patients did not reveal any significant differences in the responses. When asked if the entire investigation and dietary guidance was worthwhile $93.0 \%$ of patients responded affirmatively. The consensus was that increased awareness of food offenders had either reduced their discomfort or had provided reassurance that no serious illness was responsible for their symptoms (except for patients with Crohn's disease).

\section{DISCUSSION}

The aim of this study was to determine whether intolerance to fructose and/or sorbitol was clinically relevant to those lactose intolerant patients whose symptoms had only been partially alleviated by adherence to appropriate measures for lactose intolerance. What percentage of patients in this category would be intolerant to fructose and/or sorbitol and what percentage would benefit from appropriate dietary measures in an attempt to alleviate the postcibal discomfort and 
TABLE 2

Results of questionnaire completed by 60 patients ( $78 \%$ female)

\section{SEVERITY OF SYMPTOMS}

$\begin{array}{lccc} & \begin{array}{c}\text { Insignificant or } \\ \text { uncertain (\%) }\end{array} & \text { Minor problem (\%) } & \text { Major problem (\%) } \\ \text { Lactose } & 5 & 20 & 75 \\ \text { Fructose } & 14 & 26 & 60 \\ \text { Sorbitol } & 9 & 36 & 55\end{array}$

SYMPTOMATIC RESPONSE TO DIETARY MEASURES

Insignificant or

uncertain (\%) Some benefit $(<50 \%)(\%)$ Significant benefit $(\geq 50 \%)(\%)$

$\begin{array}{llll}\text { Lactose* }^{*} & 13 & 25 & 62 \\ \text { Fructose } & 16 & 44 & 40 \\ \text { Sorbitol } & 13 & 40 & 47\end{array}$

ADHERENCE TO APPROPRIATE DIETARY MEASURES

Yes (\%)

No $(\%)$

Lactose *

92

8

Fructose

86

14

Sorbitol

85

15

Was investigation and

93

7

dietary guidance

worthwhile?

"Includes the use of beta-galactosidase (no enzyme replacements are available yet for fructose and/or sorbitol infolerance)

other symptoms associated with these additional intolerances?

In this study we have shown that at least $75 \%$ of lactose intolerant patients whose postcibal discomfort was not eliminated entirely by appropriate dietary measures have demonstrable intolerance to fructose and/or sorbitol. While most patients were free from demonstrable organic gastrointestinal disease and could be categorized as suffering from IBS, $8.7 \%$ had Crohn's disease involving the distal small intestine (terminal ileum). Our results agree with previous studies that failed to demonstrate any sex-related differences in the incidence of fructose and/or sorbital intolerance (1) even though the male:female sex ratio of subjects studied is 1:2-3 (9). The incidence of biopsy documented gastritis, minor nonspecific abnormalities on radiologic examination of the small bowel (small bowel follow-through) and colonic diverticulosis ranged from 12 to $21 \%$ in both males and females. A history of diarrhea was obtained more often in males $(21.2 \%$ in males versus $8.5 \%$ in females) and foreign travel in females $(7.0 \%$ in females versus $3.0 \%$ in males). Thus far the signifi- cance of the correlations observed remain uncertain, especially in the absence of a control group. While it would have been of interest to have a control group of nonlactose intolerant subjects who were tested for intolerance to fructose and/or sorbitol, any control group assembled would have to be matched for ethnic heritage in addition to age and sex. We have experienced great difficulty in attempting to recruit such a control group. In a recent study designed to determine the incidence of lactose intolerance among 222 patients with inflammatory bowel disease, we noted that refusal to undergo lactose breath testing was highest among patients with the lowest risk of having lactose intolerance by virtue of their ethnic heritage (10). Based on these considerations it was decided to forego accumulating a less than valid control group.

Fructose and sorbitol absorption in humans appears to take place slowly by an energy independent low capacity facilitated transport system. Another pathway for fructose may be glucose dependent and of high capacity (8). Fructose and sorbitol may compete with each other for absorption along these pathways while glucose will facilitate the absorption of fructose. It appears that in most cases malabsorption of fructose and/or sorbitol represents a physiological rather than a pathological condition in view of the very high incidences reported: up to $60 \%$ in healthy adults $(4,6,11,12)$. Additional factors that can influence the absorption of sorbitol and fructose include osmolalities of solutions, velocity of gastric emptying, intestinal and whole gut transit, adaptation of the colonic flora $(4,13)$ as well as bacterial overgrowth. The doses of fructose ( 25 g) and sorbitol ( $5 \mathrm{~g})$ used in the standard breath testing challenges correspond to amounts normally consumed. It is estimated that the average daily intake of fructose in the United States is 7 to $10 \mathrm{~g}$ (13). With the $55 \%$ fructose content of high fructose syrup currently available, drinking about $500 \mathrm{~mL}$ of soda would result in the ingestion of $37.5 \mathrm{~g}$ fructose. The major natural source of fructose is fruit; dried figs, dates, prunes and grapes contain the largest amounts: $30.9,23.9,15.0$ and $8.0 \mathrm{~g} / 100 \mathrm{~g}$ of edible portion, respectively $(4,15)$. The sorbitol content of sugar-free gum and mints ranges from 1.3 to $2.2 \mathrm{~g} /$ piece while pears, prunes, peaches and apple juice contain 4.6, $2.4,1.0,0.9 \mathrm{~g} / 100 \mathrm{~g}$ of dry matter or juice (15). Sorbitol is commonly used as a sweetener in dietetic foods (5), and the practice of incorporating $5 \mathrm{~g}$ sorbitol into the barium administered during small bowel follow-through examinations may account for the laxative effect and severe discomfort experienced by some patients. Ironically this malabsorbed sorbitol is almost completely digested by the colonic flora yielding an energy value close to that of sucrose (13).

The incidence of incomplete absorption of fructose (based on a $25 \mathrm{~g}$ challenge and at least a $10 \mathrm{ppm}$ increase in breath $\mathrm{H}_{2}$ ) may approach 37 to $50 \%(1,6)$, while figures quoted for the incomplete absorption of sorbitol ( $5 \mathrm{~g}$ challenge and at least a $10 \mathrm{ppm}$ increase in breath $\mathrm{H}_{2}$ ) range up to $60 \%$ of healthy adult subjects $(14,16)$. The incidence of incomplete absorption or intolerance to both fructose $(25 \mathrm{~g})$ and 
sorbitol ( $5 \mathrm{~g}$ ), administered as separate challenges, has not been studied directly. Thus the values recorded for the incidence of intolerance to fructose and sorbitol in our study - namely 17.3 and $18.3 \%$, respectively - are significantly lower than those mentioned above. The fact that our patients were labelled as intolerant only if they experienced symptoms in addition to appropriate elevations of breath $\mathrm{H}_{2}$ may partially explain these apparent discrepancies.

It should be noted that studies documenting the incidence of malabsorption following the administration of solutions containing both fructose ( 25 $\mathrm{g}$ ) and sorbitol $(5 \mathrm{~g})$ (1) recorded incidences among 73 patients with IBS and 87 age- and sex-matched controls of 45.2 and $57.5 \%$, respectively. The higher incidence of malabsorption noted after the combined administration of fructose and sorbitol (instead of administering each sugar separately as was done in our study) was attributed to

ACKNOWLEDGEMENTS: The authors acknowledge the statistical analysis by Dr Morty Yalovsky (Faculty of Management, McGill University) as well as the typing, editing and preparation of graphic material by Daniel Mishkin.

\section{REFERENCES}

1. Fritz Nelis G, Vermeeren MAP, Jansen W. Role of fructose-sorbitol malabsorption in the irritable bowel syndrome. Gastroenterology 1990;99:1016-20.

2. Read NW. Irritable bowel syndrome (IBS)-definition and physiology. Scand J Gastroenterol 1987;130(Suppl):7-13.

3. Pironi L, Callegri C, Cornia GL, Lami F, Miglioli M, L Barbara. Lactose malabsorption in adult patients with Crohn's disease. Am J Gastroenterol 1988;83:1267-71.

4. Ravich WJ, Bayless TM, Thomas M. Fructose: Incomplete intestinal absorption in humans.

Gastroenterology 1983;84:26-9.

5. Urban E. Sorbitol suavities. Gastroenterology 1989;96:258-9.

6. Rumessen JJ, Gudmand-Hoyer E. Absorption capacity of fructose in the fact that each sugar interferes with the absorption of the other $(1,17)$. Based on the observation that glucose facilitates the absorption of fructose (8) it would have been of interest to have tested our patients with sucrose challenges. Although this was not done, the use of glucose is recommended to patients with fructose intolerance. We also advise patients to spread out their intake of the offending sugars throughout the day, in view of the fact that no enzyme supplement is yet available to facilitate the limited absorption of either fructose or sorbitol.

Clearly intolerance to fructose and/or sorbitol, although very common in the group of patients studied, did not explain the postcibal discomfort experienced in the $22.1 \%$ of patients who did not have additional demonstrable carbohydrate intolerances in our study. In addition, the fact that at least 53\% of patients who did not benefit significantly from modification of their intake of fructose and/or sorbitol (Table

healthy adults. Comparison with sucrose and its constituent monosaccharides. Gut 1986;27:1161-8

7. Harig JM, Soergel KH, Komorowski RA, Wood CM. Treatment of diversion colitis with short chain fatty acid irrigation. N Engl J Med 1989:320:23-8.

8. Jass JR. Diet, butyric acid and differentiation of gastrointestinal tract tumors. Med Hypotheses 1985; 18:113-8.

9. Thompson WG. The irritable bowel. Gut 1984;25:305-20.

10. Mishkin B, Yalovsky M, Mishkin S. Lactose intolerance and/or sensitivity to dairy products in patients with inflammatory bowel disease: Incidence and clinical significance. Gastroenterology 1993;104:A1052.

11. Corazza GR, Strocchi A, Rossi R, et al. Sorbitol malabsorption in normal volunteers and in patients with coeliac disease. Gut 1988;29:44-8.

12. Montes RG, Perman JA. Clinical assessment of carbohydrate malabsorption. Semin Pediatr Gastroenterol Nutr 1991;2:2-9.

13. Beaugerie L, Flourie B, Marteau P, Pellier P, Franchisseur C, Rambaud JC. Digestion and absorption in the
2) suggests that other intolerances, as yet undefined, were operative in these fructose and/or sorbitol intolerant individuals. The lower pain threshold of IBS patients $(2,18)$ and discomfort related to the malabsorption of complex carbohydrates (19) represent other avenues to be explored. Patient feedback obtained from a questionnaire completed six to 12 months following testing and dietary advice indicated that intolerance to lactose was associated with the most significant symptoms as well as the greatest benefit from appropriate dietary measures which included the use of beta-galactosidase enzyme supplements. Patients perceived that intolerance to fructose and/or sorbitol was less problematic and less responsive to dietary measures than was lactose intolerance. In spite of this, most patients (93\%) felt that they had benefited from the investigation, dietary guidance and reassurance that, in most cases, no serious disease process was responsible for their discomfort.

human intestine of three sugar alcohols. Gastroenterology 1990;99:717-23.

14. Rumessen JJ, Gudmand-Hoyer E. Functional bowel disease:

Malabsorption and abdominal distress after ingestion of fructose, sorbitol and fructose-sorbitol mixtures. Gastroenterology 1988;95:694-700.

15. Hardinge MG, Swarner JB, Crooks H. Carbohydrates in foods. J Am Diet Assoc 1965;46:197-204.

16. Hyams JS. Sorbitol intolerance: An unappreciated cause of functional gastrointestinal complaints. Gastroenterology 1983;84:30-3.

17. Rumessen JJ, Gudmand-Hoyer E. Malabsorption of fructose-sorbitol mixtures. Interactions causing abdominal distress. Scand J Gastroenterol 1987;22:431-6.

18. Ritchie J. Pain distention of the pelvic colon by inflating a balloon in the irritable bowel syndrome. Gut 1973;14:125-32.

19. Levitt MD, Hirsh P, Fetzer CA, Sheahan $\mathrm{M}$, Levine AJ. $\mathrm{H}_{2}$ excretion after ingestion of complex carbohydrates. Gastroenterology 1987;92:383-9. 


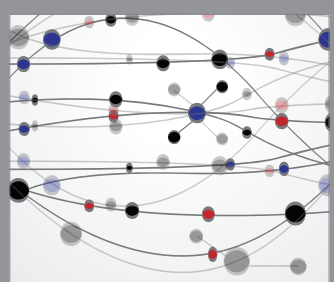

The Scientific World Journal
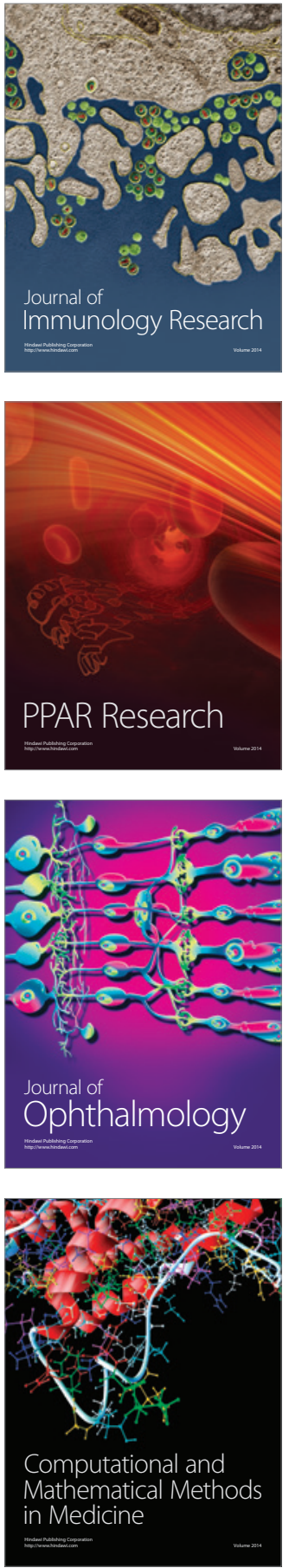

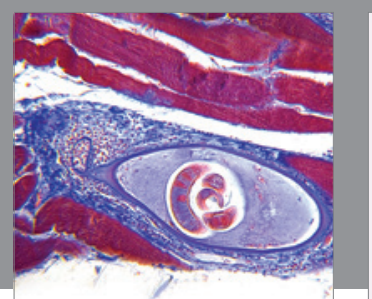

Gastroenterology Research and Practice

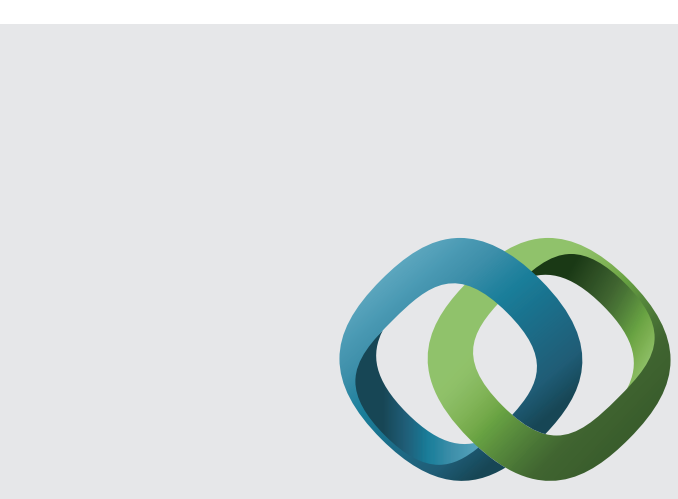

\section{Hindawi}

Submit your manuscripts at

http://www.hindawi.com
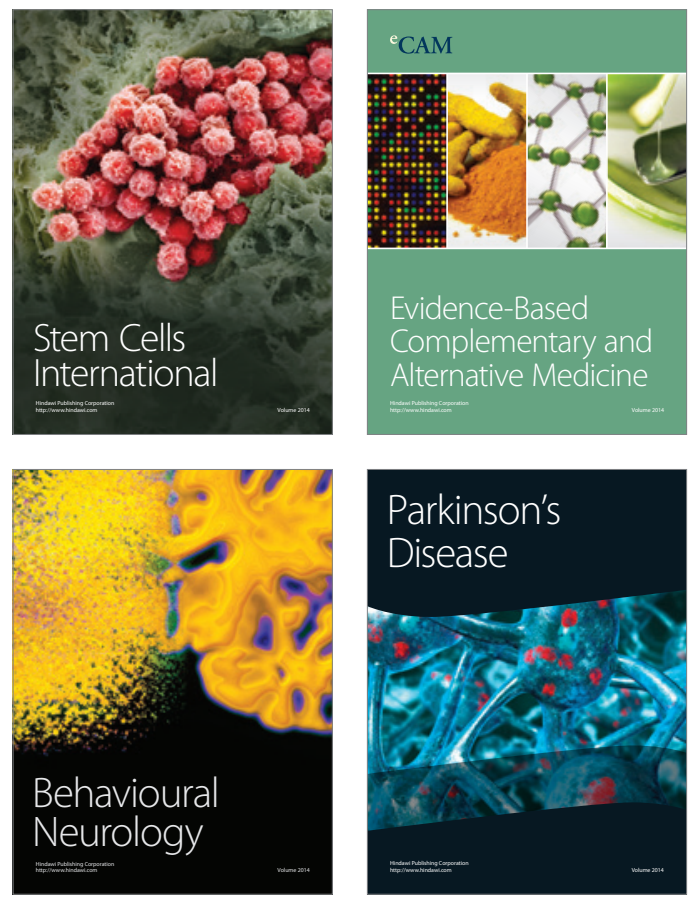
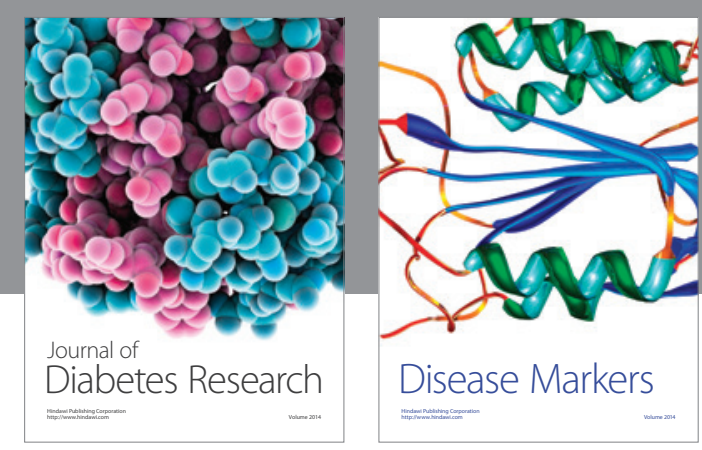

Disease Markers
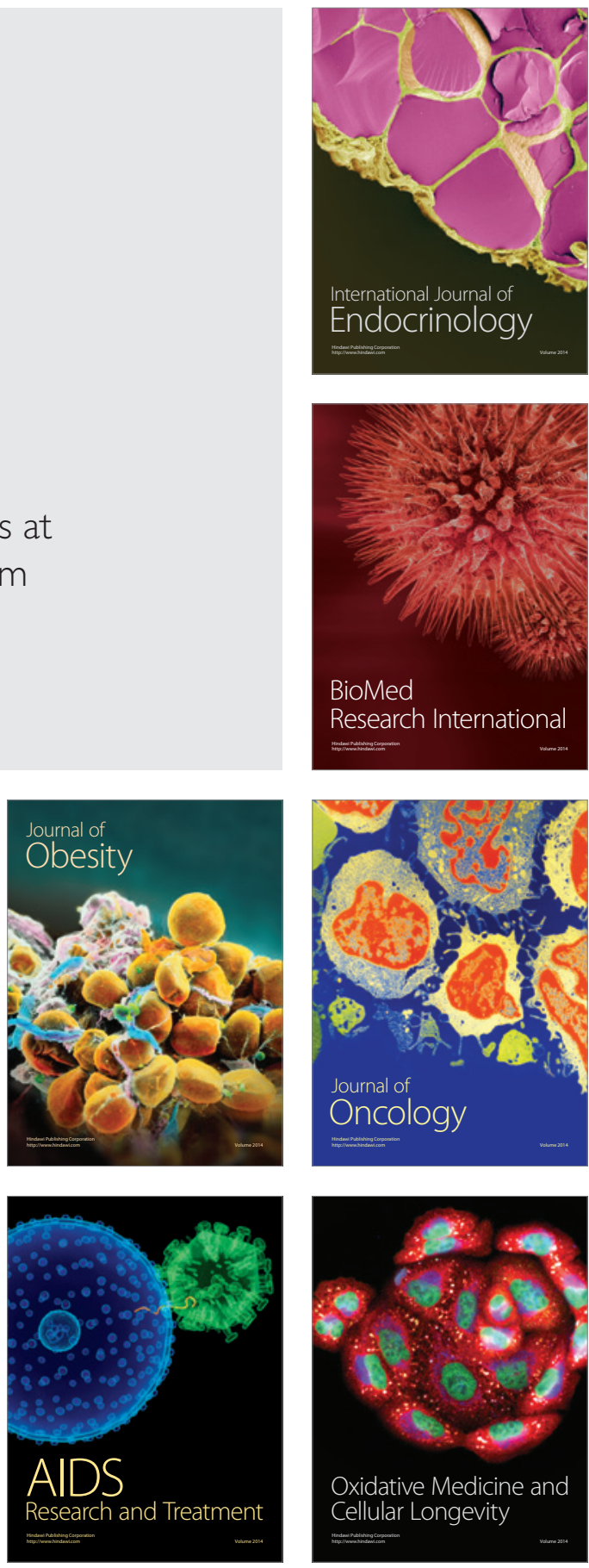